REFTRENCES

Chapman, S. and Cowling, T. G. (1939). Mathematical Theory of Non-uniform Gases, p. 252. Cambridge University Press.

Chapman, S. and Dootson, F. W. (1917). Phil. Mag. 33, 248.

Clausius, K. and Dickel, G. (1938, 1). Naturwissenschaften, 26, 546.

Clausius, $K$. and Dickel, G. $(1938,2)$. Naturwissenschaften, 27, 487.

Dole, M. $(1936,1)$. J. Amer. chem. Soc. 58, 580.

Dole, M. $(1936,2)$. J. Amer, chem. Soc. 58, 2552.

Evans, R. D. (1941). J. appl. Phys. 12, 262.

Evans, R. D. (1944). Medical Physics. [Ed. Glasser]. p. 643. New York: The Year Book Publishers.

Evans, R. D. and Mugele, R. A. (1936). Rev. sci. Instrum. 7, 441.

Fenske, M. R., Tongberg, C. O. and Quiggle, D. (1934). Industr. Engng Chem. 26, 1169.

Foster, G. L., Schoenheimer, R. and Rittenberg, D. (1939). J. Jiol. Chem. 127, 321.

Gaunt, W. E., Griffith, H. D. and Irving, J. T. (1942). J. Physiol. 100, 372.

Hevesy, G. V. (1923). Biochem. J. 17, 439.

Tbbs, T. L. and Grew, K. E. (1931). Proc. R. phys. Soc. Lond. 43, 142.

Keston, A. S. (1944). Medical Physics. [Ed. Glasser]. p. 658. New York: The Year Book Publishers.

Lewis, G. N. (1933). J. Amer. chem. Soc. 55, 1298.

Lifschutz, H. (1939). Rev. sci. Instrum. 10, 21.

Loofbourow, J. R. (1940). Rev. mod. Phys. 4, 267.

MeKay, H. A. C. (1941). Rev. sci. Instrum. 12, 104.

Nier, A. O. (1940). Phys. Rev. 57, 31.

Nier, A. O. and Gulbransen, E. (1939). J. Amer. chem. Soc. 61, 697.

Ruben, S. and Kamen, M. D. (1941). J. appl. Phys. 12, 311.

Schoenheimer, R. and Rittenberg, D. (1939). J. biol. Chem. 127, 285.

Seaborg, G. T. (1944). Rev. mod. Phys. 16, 3.

Smith, J. H. C. and Cowie, D. B. (1941). J. appl. Phys. 12, 78.

Smyth, H. D. (1945). Atomic Energy, p. 70. London: H.M.S.O.

Szilard, L. and Chalmers, W. (1934). Nature, Lond., 134, 462.

Taylor, H. S. (1939). Nature, Lond., 144, 8.

Thode, H. G. and Urey, H. C. (1939). J. ehem. Phys. 7, 36.

Urey, H. C. (1941). J. appl. Phys. 12, 270.

\title{
Modern Methods of Studying Protein Metabolism
}

\section{Dr. J. N. Davidson (National Institute for Medical Research, Hampstead, London, N.W.3)}

The most important advance of recent years in methods of studying protein metabolism has undoubtedly been the application of the use of isotopes for following metabolic patbways. For this purpose the nitrogen isotope $\mathbb{N}^{15}$ has been extensively employed by Schoenheimer (1942) and his colleagues, but other isotopes such as deuterium, $\mathrm{C}^{13}$ and $\mathrm{S}^{34}$ have also been used on a smaller scale.

The isotope $\mathrm{N}^{15}$ normally occurs to an extent of 0.368 per cent. in the nitrogen of inorganic and organic compounds and of the air, and the cells of animal and plant tissues are therefore accustomed to both $\mathrm{N}^{14}$ and $\mathrm{N}^{15}$ and treat them indiscriminately. Hence a physiological compound in which the concentration of $\mathrm{N}^{15}$ has been artificially raised will not constitute a substance foreign to the organism. The carbon-nitrogen linkage of amino- and guanido-compounds is relatively stable in vitro so that loss of $\mathrm{N}^{15}$ from an amino-acid will oceur only when chemical reactions take place at the amino-group (Schoenheimer and Rittenberg, 1939; Keston, Rittenberg and Schoenheimer, 1939).

voL. 4,1946 ] 
Heavy nitrogen is usually available in the form of ammonium salts which can be used for the synthesis of amino-acids. Such labelled aminoacids have been fed to rats in nitrogen equilibrium on a diet containing adequate amounts of protein, and the excreta and tissues have subsequently been analysed for $\mathrm{N}^{15}$. Instead of appearing directly in the urine in the form of labelled urea, as would be expected according to the classical view, a large proportion of the $\mathrm{N}^{15}$ remains in the protein fraction of the tissues. The highest concentration is found in the serum proteins, in the intestinal mucosa, and in the kidney, spleen and liver, but $\mathbf{N}^{15}$ can be detected even in tissues such as tendon which are usually considered to be metabolically relatively inert. Some two-thirds of the total $\mathrm{N}^{15}$ retained is found in the muscles.

When the individual amino-acids of the tissue proteins are examined, the heavy nitrogen is found not only in the amino-acid corresponding to the one fed, but in most of the other amino-acids as well, with the exception of lysine. If, for example, labelled leucine is fed, $\mathrm{N}^{15}$ can be found not only in the leucine of the tissue proteins, but also in the glycine, arginine and tyrosine, and in particularly large amounts in the dicarboxylic amino-acids, glutamic acid aud aspartic acid, which are active in the process of transamination. A similar labelling of the amino-acids of the tissue proteins follows the feeding of isotopic ammonium salts.

It appears, therefore, that the nitrogen of any one amino-acid of the diet can be transferred quickly and easily to other amino-acids, probably through the agency of keto-acids in the process of transamination. Amino-acids derived from the protein of the food, or formed in the tissues in this way, can then replace their analogues in the tissue proteins. This means that the peptide bonds of the tissue proteins can open and close as amino-acids are taken out of the protein molecule and are replaced by new ones of the same kind. This occurs even when protein is abundant in the diet and when there is no suggestion of nutritional amino-acid deficiency, and the process takes place even in the relatively inert tissues such as skin, hair and tendon.

These results have revealed that the tissue proteins are not in a static condition but are in a constant state of flux. Peptide linkages open to allow amino-acids to be removed and replaced. Those which are released mingle with the amino-acids of dietary origin or with those derived from other sources in the tissues. Some amino-acids from this general stock or "pool" fill the vacant places in the protein chains; others take part in transamination processes, transferring their amino-groups to keto-acids derived from previously de-aminated molecules; others again take part in creatine formation or in such cyclic processes as the arginine cycle for urea formation. The nitrogenous compounds in the tissues thus form what Schoenheimer (1942) termed "a metabolic pool of components indistinguishable as to origin".

Under these circumstances the terms "exogenous" and "endogenous" metabolism lose their original meaning. Excreted nitrogen must be regarded as derived from the general metabolic pool in which nitrogenous compounds from the diet and from the tissues are inextricably intermingled.

For the study of the essential amino-acids it may be convenient to introduce two different isotopes into the one amino-acid molecule in 
order that the amino-group and the carbon chain may be separately traced. Lysine (I) and leucine (II) containing $\mathrm{N}^{15}$ and carbon-bound deuterium have been employed in this way.

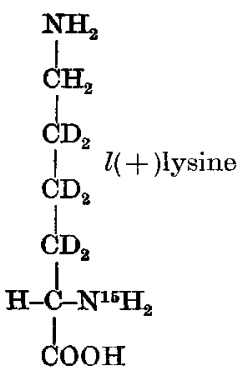

(I)

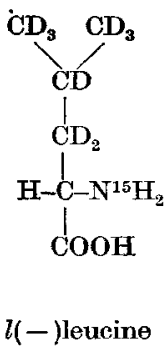

(II)<smiles>CC(C)CC(=O)O</smiles>

(III)<smiles>CCCCC(N)C(O)C(=O)O</smiles>

(IV)

The results obtained with such doubly labelled compounds have revealed that the essential amino-acids, for the rat at least, fall into two main groups. The larger group consists of amino-acids which can be replaced in the diet by their de-amination products such as the corresponding $\alpha$-keto-acids or $\alpha$-hydroxy-acids. For example the rat can synthesize leucine from the corresponding keto-acid (III) or histidine from imidazole lactic acid. Essential amino-acids of this group contain two metabolically independent groupings, the carbon chain and the amino group. The carbon chain is indispensable and cannot be built up by the animal, but the amino group can be attached to it without difficulty. The amino-acids of this group take part in the reversible nitrogen shift, giving up nitrogen to yield the corresponding keto-acid which can in turn take up an amino group with restoration of the original amino-acid.

The second group of essential amino-acids consists of lysine alone. When lysine containing $\mathrm{N}^{15}$ in the $\alpha$-amino-position is fed to animals, the heavy nitrogen can subsequently be located in other amino-acids, but the keto-acid corresponding to lysine cannot take up nitrogen to yield lysine. Nor is $\mathrm{N}^{15}$ ever found in the lysine of the tissue proteins after administration of $\mathrm{N}^{15}$ in the form of any other dietary amino-acid. Lysine therefore does not take part in the reversible nitrogen shift, and it cannot be replaced in the diet by the corresponding keto-acid. In this case the whole molecule, carbon chain with amino-group attached, is indispensable as one single unit (Weissman and Schoenheimer, 1941).

Since lysine is an amino-acid which does not take up $\mathrm{N}$ from any other amino-acids to any appreciable extent, it forms a useful means of labelling proteins. Fink, Enns, Kimball, Silberstein, Bale, Wadden and Whipple (1944) have made use of it to follow plasma protein metabolism during shock. They administered to dogs lysine containing $\mathrm{N}^{\mathbf{1 5}}$ in the $\epsilon$-aminoposition together with an adequate supply of other essential amino-acids. The concentration of $\mathrm{N}^{15}$ in the lysine of the plasma proteins eventually reached a sufficiently high level for the $\mathrm{N}^{15}$ to be measured accurately even after considerable dilution. Such labelled plasma proteins were biologically indistinguishable from proteins of normal isotope concentration. When they were injected, as plasma, into normal dogs, they voL. 4,1946$]$ 
passed out of the blood stream at an initially rapid but constantly decreasing non-logarithmic rate. This outflow was balanced by a simultaneous inflow of plasma protein from the tissues. In 24 hours 50 per cent. of the labelled protein had passed out of the blood stream and in 6 days 75 per cent. had passed out. The results indicate that the plasma proteins are normally in constant and rapid exchange with a mobile pool of body protein.

Isotopes of carbon and sulphur have proved particularly valuable in the study of the metabolism of methionine. It has been known for a long time that methionine can be converted to cystine in the tissues. This has been confirmed by the use of methionine containing labelled $S$ and several routes for the conversion have been proposed, some involving the sulphur atom only, while others have made use of the carbon chain as well. The bulk of the evidence has favoured the view that the sulphur atom alone of cystine comes from methionine, while the carbon chain is derived from serine. When serine containing $\mathrm{N}^{15}$ is fed to rats, a high isotope content is found in the cystine isolated from the tissue proteins (Stetten, 1942). Moreover, rat liver tissue can convert a mixture of homocysteine and serine to cysteine, while only slight cysteine formation takes place in the absence of serine (Binkley and Du Vigneaud, 1942). The most likely mechanism for cystine formation from methionine appears to involve the thio-ether $l l$-S- $(\beta$-amino- $\beta$-carboxyethyl)-homocysteine (cystathionine) thus:

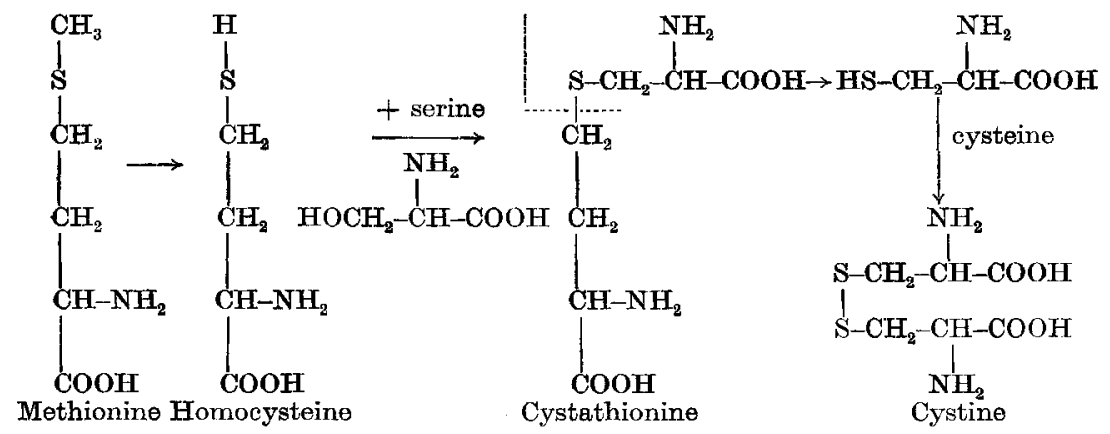

Support for this view has been obtained by the use of methionine containing $\mathrm{S}^{34}$ and $\mathrm{C}^{13}$ (IV, p. 251) (Du Vigneaud, Kilmer, Rachele and Cohn, 1944). When it was fed to rats, the cystine subsequently isolated from the hair contained $\mathrm{S}^{34}$ but no appreciable amount of $\mathrm{C}^{13}$. The carbon chain of methionine is therefore not utilized in the conversion to eystine.

Finally, brief mention might be made of the application of isotopes to the study of nucleoprotein metabolism. When labelled ammonium salts are fed to the rat the nitrogen passes to the general labile pool and thence by way of the arginine cycle to urea. Small amounts appear in the purines and pyrimidines of the nucleic acids. In the pigeon the feeding of labelled ammonium salts is followed by the appearance of the $\mathrm{N}^{15}$ in the amino-acids of the tissue proteins, particularly aspartic acid and glutamic acid but not arginine, in the purines and pyrimidines of the nucleic acids of the tissues, particularly the liver and gastro-intestinal tract, 
but not to any great extent in the muscle adenylic acid, and in the excreted uric acid (Barnes and Schoenheimer, 1943). It appears that the pathway from ammonia to uric acid in the bird passes through the purines and pyrimidines of the tissue nucleic acids. The following scheme shows the metabolic pathways in the rat and in the pigeon:

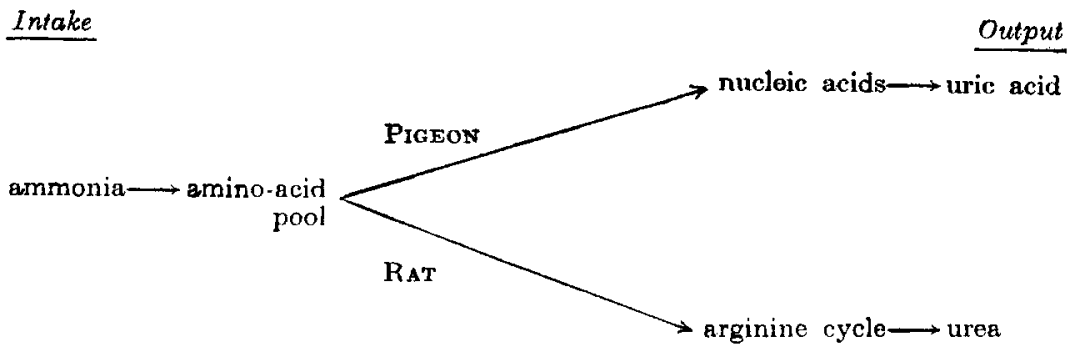

The use of $\mathrm{N}^{15}$ has also revealed that the pigeon does not employ urea, arginine or histidine in the synthesis of purines (Barnes and Schoenheimer, 1943), nor can dietary purines be used in nucleic acid synthesis. When isotopic guanine is fed to pigeons the isotope appears in the uric acid excreted but not in the tissue nucleic acid (Plentl and Schoenheimer, 1944). The nucleoproteins therefore appear to be built up from smaller molecules in the general metabolic pool, and not from dietary purines or pyrimidines, although there is some evidence that the latter may be utilized if they are supplied as nucleosides or nucleotides, instead of as free bases.

\section{REFERENCES}

Barnes, F. W. and Schoenheimer, R. (1943). J. biol. Chem. 151, 123.

Binkley, J. and Du Vigneaud, V.(1942). J. biol. Chem. 144, 507.

Du Vigneaud, V., Kilmer, G. W., Rachele, J. R. and Cohn, M. (1944). J. biol. Chem. 155, 645.

Fink, R. M., Enns, T., Kimball, C. P., Silberstein, H. E., Bale, W. F., Wadden, S. C. and Whipple, G. H. (1944). J. exp. Med. 80, 455 .

Keston, A. S., Rittenberg, D. and Schoenheimer, R. (1939). J. biol. Chem. 127, 315.

Plentl, A. A. and Schoenheimer, R. (1944). J. biol. Chem. 153, 203.

Schoenheimer, R. (1942). The Dynamic State of Body Constituents. Harvard University Press.

Schoenheimer, R. and Rittenberg, D. (1939). J. biol. Chem. 127, 285.

Stetten, D. (1942). J. biol. Chem. 144, 501.

Weissman, N. and Schoenhoimer, R. (1941). J. biol. Chem. 140, 779.

\section{Discussion}

Dr. 1. Leitch (Imperial Bureau of Animal Nutrition, Bucksburn, Aberdeen): I have recently read an interesting paper which suggested that in the organisms studied, all mutations were characterized by the loss of power to synthesize one or other complex chemical compound. Some of these were essential to survival, some not. If this is true and if evolution is by selection of successive mutations then the higher the stage in evolution, the more dependent the organism must be for survival on the diet available.

voL. 4,1946$]$ 